\title{
KAITAN PENGGUNAAN OBAT ANALGETIK DAN ANTI INFLAMASI NON STEROID DENGAN KEJADIAN GAGAL GINJAL KRONIK PADA PASIEN HEMODIALISIS DI RSU PKU MUHAMMADYAH YOGYAKARTA
}

\author{
Woro Supadmi ${ }^{* 1}$, Lukman Hakim ${ }^{2}$ \\ ${ }^{1}$ Fakultas Farmasi, Universitas Ahmad Dahlan, Yogyakarta \\ *e-mail: wsupadmi@yahoo.com
}

\begin{abstract}
ABSTRAK
Gagal ginjal kronik merupakan masalah kesehatan, sosial dan ekonomi dengan peningkatan insidensi, prevalensi dan morbiditas. Penelitian ini bertujuan untuk mengetahui apakah ada kaitan dan nilai odds ratio antara penggunaan analgetik dan OAINS dengan kejadian GGK di RSU PKU Muhammadiyah Yogyakarta. Penelitian ini menggunakan rancangan case control, kelompok kasus adalah pasien gagal ginjal kronik yang melakukan hemodialisa dan kelompok kontrol adalah pasien yang melakukan rawat inap tidak terdiagnosa GGK. Data sekunder diperoleh dari rekam medik pasien, data primer diperoleh melalui wawancara mendalam dengan panduan lembar pertanyaan. Data dianalisis dengan tabel 2x2 chi-square. Hasil penelitian menunjukkan bahwa penggunaan analgetik tidak berkaitan dengan kejadian GGK (OR $0,1 ; p>0,05 ; \mathrm{Cl} \quad 0,018-0,366)$. Penggunaan OAINS berkaitan dengan kejadian GGK (OR $4,4 ; \mathrm{p}<0,05 ; \mathrm{Cl} \quad 0,906-21,97)$. Penggunaan analgetik dan OAINS berkaitan dengan kejadian GGK (OR 5,1;p<0,05;Cl 1,05724,78). Lama penggunaan analgetik tidak berkaitan dengan kejadian GGK (OR $1,4 ; p>0,05 ; \mathrm{Cl} \quad 0,307-5,94)$, jumlah tablet penggunaan analgetik berkaitan dengan kejadian GGK (OR 23; $p<0,05 ; \mathrm{Cl} 3,981-131$ ). Lama penggunaan OAINS tidak berkaitan dengan kejadian GGK (OR 0,$4 ; p>0,05 ; \mathrm{Cl}$ $0,018-7,29)$, jumlah tablet penggunaan OAINS berkaitan dengan kejadian GGK (OR $12 ; \mathrm{p}<0,05 ; \mathrm{Cl} 0,936-153)$. Lama penggunaan analgetik dan OAINS tidak berkaitan dengan kejadian GGK (OR 0,6;p>0,05;Cl 0,036-6,9), jumlah tablet penggunaan analgetik dan OAINS tidak berkaitan dengan kejadian GGK (OR 1,$1 ; p>0,05 ; C l ~ 0,138-7,934$ ).
\end{abstract}

Kata kunci : analgetik, faktor risiko, GGK (Gagal Ginjal Kronik), OAINS
ABSTRACT

Chronic renal failure is a matter of health, social and economi with increasing incidence, prevalence and morbidity. This study was aimed to observe assosiation between the used of analgesics and NSAIDs and calculate odds ratio of chronic renal failure incidence at PKU Muhammadiyah Hospital in Yogyakarta. The study used analytical observation with case control desingn,group of case cosisted as chronic renal failure patients who do hemodialysis and group of control who are not diagnosed with chronic renal failure. Secondary data were obtained from patient's medical records the primary data were obtained through indepth interview by guided questionnaire. Data analysis was using the $2 \times 2$ table and analyzed with chi square test to find out the correlation and the odds ratio between the use of analgesics and NSAIDs of chronic renal failure incidance. The used of analgesics not assosiation of chronic renal failure incidence (OR $0.1 ; \mathrm{p}>0.05 ; \mathrm{Cl} 0.018$ to $0,366)$. The used of NSAIDs assosiation of chronic renal failure incidence (OR 4.4; $\mathrm{p}<$ 0,$05 ; \mathrm{Cl} 0.906$ to 21.97). The used of analgesics and NSAID assosiation of chronic renal failure incidence (OR $5.1 ; \mathrm{p}<0.05 ; \mathrm{Cl}$ 1.057 to 24.78). Duration of the used of analgesics not assosiation of renal failure incidence (OR $1.4 ; \mathrm{p}>0.05 ; \mathrm{Cl} 0.307$ to 5.94 ), the used total tablets analgesics correlation of chronic renal failure incidence (OR $23 ; p<0.05 ; \mathrm{Cl} 3.981$ to 131$)$. Duration of the used of NSAIDs was not assosiation of chronic renal failure incidence (OR $0.4 ; p>0.05 ; \mathrm{Cl} 0.018$ to 7.29 ), number of totals tablets NSAIDs assosiation of chronic renal failure incidence (OR $12 ; \mathrm{p}<0.05 ; \mathrm{Cl}$ 0.936 to 153). Duration of the used of analgesics and NSAIDs were not assosiation of chronic renal failure incidence (OR $0.6 ; p>0.05 ; \mathrm{Cl} 0.036$ to 6.9 ), number of totals tablets to the used of analgesics and 
NSAIDs were not assosiation of chronic renal failure incidence (OR 1.1; $\mathrm{p}>0.05 ; \mathrm{Cl}$ 0.138 to 7.934 ).

Keywords: analgesics, chronic renal failure, NSAIDs, risk factors

\section{PENDAHULUAN}

Gagal ginjal kronik merupakan masalah kesehatan, sosial dan ekonomi dengan peningkatan insidensi, prevalensi dan morbiditas. Gagal ginjal kronik memerlukan biaya perawatan yang mahal dengan hasil perawatan yang buruk (NKF, 2004). Angka kematian akibat gagal ginjal kronik atau end stage renal disease terus meningkat di banyak negara termasuk negara berkembang seperti di Indonesia (Strong et al, 2005 ).

Insidensi tahunan gagal ginjal kronik dilaporkan bervariasi di Amerika pada tahun 2000 sebesar 1.311 per satu juta penduduk dengan jumlah penderita sebesar 20 juta dan diperkirakan pada tahun 2025 akan mencapai dua kalinya. Angka kejadian gagal ginjal kronik di Jepang, Australia dan Inggris mencapai $77-283$ orang per 1.000 .000 penduduk. Angka kejadian penderita gagal ginjal kronik di Indonesia, sampai sekarang belum ada data yang akurat dan lengkap, namun diperkirakan penderita gagal ginjal kronik kurang lebih 50 orang per satu juta penduduk (Suhardjono et al, 2001).

Insidensi gagal ginjal kronik di Yogyakarta diperkirakan sebesar 1000 orang tiap 1 juta penduduk atau seorang penderita tiap 1.000 penduduk. Rumah sakit yang melayani hemodialisa adalah RSUP Dr. Sardjito, RS PKU Muhammadiyah, RS Panti Rapih dan RS Bethesda. Gambaran pelaksanaan pelayanan hemodialisa bulanan di beberapa Rumah Sakit mulai bulan
Januari sampai bulan Agustus 2006 sebagai berikut; RS Bethesda melayani 91 pasien dengan 636 kali cuci darah, RSU PKU Muhammadiyah sebesar 244 pasien dengan 1.927 kali cuci darah dan RS Panti Rapih sebesar 364 pasien, 2.412 kali cuci darah (Kompas, 5/8/2006).

Banyak faktor risiko yang mempengaruhi kejadian gagal ginjal kronik, dari hasil penelitian faktor-faktor yang diduga berhubungan dengan kejadian gagal ginjal kronik adalah usia, ras, jenis kelamin dan riwayat penyakit keluarga, pemakaian obat analgetik, OAINS dan diabetes (Mcclellan dan Flanders, 2003). Beberapa bukti epidemiologis menunjukkan bahwa terdapat hubungan antara penggunaan analgetika dan antiinflamasi non steroid secara berlebihan dengan kejadian kerusakan ginjal atau nefropati (De Broe et al, 1996; Fored et $a l, 2003)$.

\section{METODE PENELITIAN}

Penelitian ini merupakan penelitian kasus - kontrol menggunakan rancangan hospital based case control study dengan menelusuri ke belakang apakah ada kaitan antara riwayat penggunaan analgetik dan OAINS dengan kejadian gagal ginjal kronik pada pasien yang melakukan hemodialisis di rumah sakit PKU Muhammadiyah Yogyakarta. Analgetik adalah paracetamol dan antalgin, obat golongan NSAID adalah asam mefenamat, natrium diklofenak, kalium diklofenak, piroxicam, tenoxicam, meloxicam, ibuprofen, ketoprofen. Pasien kasus adalah pasien gagal ginjal kronik dengan hemodialisis secara rutin. Pasien kontrol adalah pasien dengan ginjal normal melakukan rawat inap dengan kondisi 
trauma, sadar dan infeksi ringan. Kriteria inklusi pasien adalah usia 15-75 tahun.

Data dianalisis dengan menggunakan tabel $2 \times 2$ dan chi-square untuk mengetahui odds ratio yang menilai kaitan antara riwayat penggunaan analgetik, penggunaan obat anti inflamasi non steroid serta penggunaan kombinasi analgetik dan obat anti inflamasi non steroid, riwayat penyakit faktor risiko gagal ginjal kronik dengan kejadian gagal ginjal kronik di RSU PKU Muhammadiyah Yogyakarta.

\section{HASIL DAN PEMBAHASAN}

Penelitian ini merupakan penelitian analitik dengan rancangan hospital based case control study Panelitian dilakukan pada bulan Januari-Desember 2009. Subyek penelitian sebagai sampel kasus adalah pasien gagal ginjal kronik dengan hemodialisis sebanyak 60 orang dan sebagai sampel kontrol adalah pasien rawat inap dengan ginjal normal berdasarkan data serum kreatinin sebanyak 60 orang. Pasien diwawancarai untuk memperoleh informasi riwayat penggunaan analgetik dan obat anti inflamasi non steroid. Beberapa bukti epidemiologis menunjukkan bahwa terdapat hubungan antara penggunaan analgetika dan anti inflamasi non steroid secara berlebihan dengan kejadian kerusakan ginjal atau nefropati.

Berdasarkan Price dan Wilson, 2002 menyatakan bahwa jenis kelamin dan usia berpengaruh terhadap kejadian penyakit glomerulonefritis yang merupakan salah satu faktor risiko gagal ginjal kronik. Distribusi responden dan kaitan jenis kelamin dan usia dengan kejadian gagal ginjal kronik pada Tabel 1.

Tabel 1. Distribusi pasien berdasarkan jenis kelamin dan usia

\begin{tabular}{lccccc}
\hline \multicolumn{1}{c}{ Karakteristik pasien } & Kasus & Kontrol & Jumlah & $\begin{array}{c}p \text { value } \\
\text { Cl 95\% }\end{array}$ & OR \\
\hline Jenis kelamin & 37 & 27 & 64 & 0,067 & 1,966 \\
$\begin{array}{l}\text { 1. Laki-laki } \\
\text { 2. Perempuan }\end{array}$ & 23 & 33 & 56 & $0,950-4,071$ & \\
Usia & & & & & \\
1. $15-45$ tahun & 18 & 31 & 49 & 0,016 & 2,494 \\
2. $46-75$ tahun & 42 & 29 & 71 & $1,179-5,276$ & \\
\hline
\end{tabular}

Usia pasien 46-75 tahun mempunyai risiko mengalami gagal ginjal kronik 2,5 kali lebih besar dari usia pasien 15-45 tahun. Hal ini menunjukkan bahwa semakin bertambah usia, semakin berkurang fungsi ginjal karena disebabkan terjadinya penurunan kecepatan ekskresi glomerulus dan penurunan fungsi tubulus pada ginjal. Jenis kelamin laki- laki mempunyai risiko mengalami gagal ginjal kronik 2 kali dari jenis kelamin perempuan, hal ini kemungkinan karena laki-laki kurang hatihati dalam penggunaan obat dan secara sosial kurang memperhatikan kesehatan.

Beberapa bukti epidemiologi menunjukkan bahwa ada hubungan antara penggunaan analgetik dan anti inflamasi non steroid secara berlebihan dengan terjadinya kerusakan ginjal atau nefropati. Nefropati analgetik merupakan kerusakan nefron akibat penggunaan analgetik (Fored et al, 2003). Hasil penelitian kaitan riwayat 
Woro Supadmi

penggunaan analgetik dengan kejadian gagal ginjal kronik pada Tabel 2.

Tabel 2. Kaitan antara penggunaan analgetik dengan kejadian gagal ginjal kronik

\begin{tabular}{lcccccc}
\hline \multicolumn{2}{c}{ Faktor risiko } & Kasus & Kontrol & Total & $\begin{array}{c}p \text { value } \\
\text { Cl 95\% }\end{array}$ & OR \\
\hline Analgetik & ya & 2 & 18 & 20 & 0,080 & 0,08 \\
& tidak & 58 & 42 & 100 & $0,018-0,366$ & \\
\hline
\end{tabular}

Penggunaan analgetik mempunyai risiko 0,08 lebih kecil mengalami gagal ginjal kronik. Hal ini kemungkinan penggunaannya tidak secara berlebihan, oleh karena itu perlu ditinjau lama dan jumlah tablet penggunaan analgetik pada pasien sehingga diketahui jumlah paparan yang menyebabkan terjadinya gagal ginjal kronik.

Lama penggunaan analgetik menggambarkan lama paparan analgetik pada ginjal yang mengakibatkan kerusakan ginjal. Lama penggunaan obat analgetik tidak selalu berkorelasi dengan jumlah obat. Lama penggunaan perlu dianalisis untuk mengetahui kaitan lama penggunaan analgetik mulai dari awal sampai pasien melakukan hemodialisa pada kelompok kasus dan sampai periode penelitian pada kelompok kontrol. Hasil penelitian kaitan lama penggunaan analgetik pada Tabel 3 .

Tabel 3. Kaitan antara lama penggunaan analgetik dan kejadian gagal ginjal kronik

\begin{tabular}{lcccccc} 
& \multicolumn{1}{c}{ Faktor risiko } & Kasus & Kontrol & Total & $\begin{array}{c}p \text { value } \\
\text { Cl 95\% }\end{array}$ & OR \\
\hline $\begin{array}{l}\text { Lama } \\
\begin{array}{l}\text { penggunaan } \\
\text { analgetik }\end{array}\end{array}$ & $1-10$ tahun & 13 & 22 & 35 & 0,688 & 1,354 \\
\hline Total & $>10$ tahun & 4 & 5 & 9 & $0,307-5,94$ & \\
\hline
\end{tabular}

Hasil analisis bivariat menunjukkan bahwa variabel lama penggunaan analgetik tidak berkaitan dengan kejadian gagal ginjal kronik (OR 1,35;p>0,05). Hal ini disebabkan karena lama penggunaan 1-10 tahun dengan frekuensi penggunaan analgetik secara terus menerus minimal 6 tablet setiap bulan, sedangkan lama penggunaan lebih dari $>10$ tahun tetapi frekuensi penggunaan tidak terus menerus yaitu setiap 2 bulan atau lebih. Secara klinik lama penggunaan analgetik
$>10$ tahun memberikan peluang 1,4 kali lebih besar mengalami gagal ginjal kronik. Hal ini menunjukkan bahwa lama penggunaan analgetik >10 tahun meningkatkan risiko terjadinya gagal ginjal kronik.

Jumlah tablet menunjukkan jumlah paparan yang merusak ginjal, oleh karena jumlah tablet penggunaan analgetik dianalisis untuk mengetahui kaitan jumlah tablet dengan kejadian gagal ginjal kronik. Hasil analisis pada Tabel 4. 
Tabel 4. Kaitan antara jumlah tablet analgetik dan kejadian gagal ginjal kronik

\begin{tabular}{lcccccc}
\hline \multicolumn{2}{c}{ Faktor risiko } & Kasus & Kontrol & Total & $\begin{array}{r}\text { p value } \\
\text { Cl 95\% }\end{array}$ & OR \\
\hline $\begin{array}{l}\text { Jumlah tablet } \\
\text { obat analgetik }\end{array}$ & $1-500$ tablet & 6 & 25 & 31 & 0,001 & 22,917 \\
& $>500$ tablet & 11 & 2 & 13 & $3,981-131$ & \\
\hline Total & & 17 & 27 & 44 & & \\
\hline
\end{tabular}

Secara klinik pada pasien yang menggunakan analgetik lebih dari $>500$ tablet mempunyai risiko 23 kali lebih besar mengalami gagal ginjal kronik. Kebiasaan menggunakan analgetik meningkatkan terjadinya penyakit gagal ginjal kronik. Penggunaan asetaminofen lebih dari 5.000 tablet selama lima tahun dapat meningkatkan kejadian penyakit ginjal stadium akhir. Lama penggunaan analgetik mempengaruhi lama paparan analgetik terhadap ginjal. Risiko terjadinya penyakit ginjal stadium akhir meningkat pada penggunaan lebih dari lima tahun (Elseviers et al, 1998)

Efek toksik akibat obat anti inflamasi non steroid tergantung dengan dosis dan lama penggunaan obat. Penelitian tentang penggunaan anti inflamasi non steroid dan gagal ginjal akut pada pasien usia lanjut dilakukan oleh Griffin et al, tahun 2000 di USA menunjukkan bahwa odds ratio penggunaan OAINS adalah 1,58 $(95 \% \mathrm{Cl}$ 1,34-1,86). Hasil penelitian kaitan penggunaan OAINS dengan kejadian GGK pada Tabel 5.

Tabel 5. Kaitan antara penggunaan OAINS dengan kejadian gagal ginjal kronik

\begin{tabular}{lcccccc}
\hline & Faktor risiko & Kasus & Kontrol & Total & $\begin{array}{c}p \text { value } \\
\text { Cl 95\% }\end{array}$ & OR \\
\hline OAINS & ya & 8 & 2 & 10 & 0,048 & 4,47 \\
& tidak & 52 & 58 & 110 & $0,906-21,97$ & \\
\hline Total & & 60 & 60 & 120 & & \\
\hline
\end{tabular}

Berdasarkan hasil analisis bivariat mengakibatkan terjadinya vasokonstriksi riwayat penggunaan OAINS berkaitan pada medula ginjal. Lama penggunaan dengan kejadian gagal ginjal kronik (OR $4,47 ; p<0,05)$. Obat anti inflamasi non steroid OAINS berkaitan dengan gagal ginjal kronik pada Tabel 6. menghambat sintesis prostaglandin yang

Tabel 6. Kaitan antara lama penggunaan OAINS dan kejadian gagal ginjal kronik

\begin{tabular}{|c|c|c|c|c|c|c|}
\hline \multicolumn{2}{|c|}{ Faktor risiko } & Kasus & Kontrol & Total & $\begin{array}{l}p \text { value } \\
\mathrm{Cl} 95 \%\end{array}$ & OR \\
\hline \multirow{2}{*}{$\begin{array}{l}\text { Lama } \\
\text { penggunaan } \\
\text { OAINS }\end{array}$} & 1- 10 tahun & 11 & 4 & 15 & 0,496 & 0,364 \\
\hline & $>10$ tahun & 1 & 1 & 2 & $0,018-7,295$ & \\
\hline Total & & 12 & 5 & 17 & & \\
\hline
\end{tabular}



Hasil analisis bivariat menunjukkan bahwa jumlah tablet OAINS berkaitan dengan kejadian gagal ginjal kronik kronik (OR 12,0;p<0,05). Secara klinik pasien yang menggunakan OAINS lebih dari $>500$ tablet mempunyai risiko 12 kali lebih besar mengalami gagal ginjal kronik pada Tabel 7 .

Tabel 7. Kaitan antara jumlah tablet OAINS dan kejadian gagal ginjal kronik

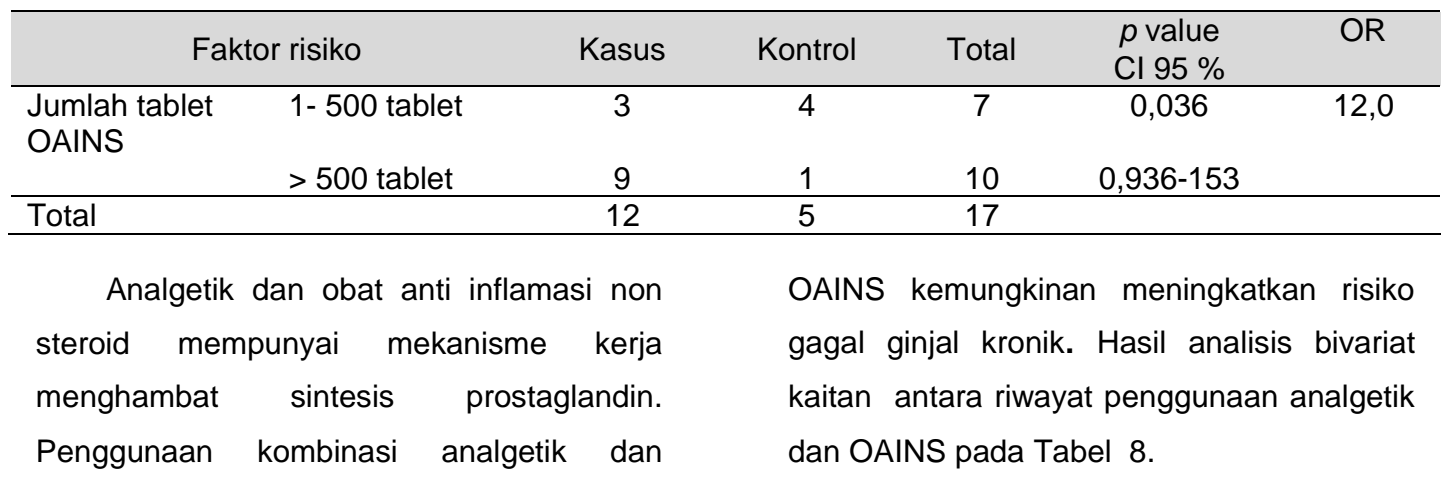

Tabel 8. Kaitan antara penggunaan analgetik dan OAINS dengan kejadian GGK

\begin{tabular}{lcccccc}
\multicolumn{1}{c}{ Faktor risiko } & Kasus & Kontrol & Total & $\begin{array}{c}P \text { value } \\
\mathrm{Cl}\end{array}$ & OR \\
\hline $\begin{array}{l}\text { Analgetik dan } \\
\text { OAINS }\end{array}$ & ya & 9 & 2 & 11 & 0,027 & 5,12 \\
& tidak & 51 & 58 & 109 & $1,057-24,78$ & \\
\hline Total & & 60 & 60 & 120 & & \\
\hline
\end{tabular}

Berdasarkan analisis bivariat penggunaan analgetik dan OAINS berkaitan dengan kejadian gagal ginjal kronik (OR 5,12;p<0,027). Penggunaan kombinasi analgetik dan OAINS meningkatkan risiko terjadinya gagal ginjal kronik 5,1 kali. Penghambatan sistensi prostaglandin yang kuat oleh OAINS dalam jangka waktu pendek sudah dapat menyebabkan vasokonstriksi renal, menurunkaan aliran darah ke ginjal dan potensial menimbulkan iskemia glomerular. Secara klinik lama penggunaan analgetik dan anti inflamasi non steroid $>10$ tahun mempunyai risiko 0,5 kali lebih kecil mengalami gagal ginjal kronik. Kemungkinan pada penelitian ini, penggunaan analgetik dan OAINS selama kurang dari 10 tahun sudah menyebabkan terjadinya gagal ginjal kronik, sehingga pasien gagal ginjal kronik menghentikan penggunaan. Kaitan lama penggunaan analgetik, OAINS dengan kejadian gagal ginjal kronik pada Tabel 9.

Tabel 9. Kaitan lama penggunaan analgetik dan OAINS dengan kejadian gagal ginjal kronik

\begin{tabular}{lcccccc}
\multicolumn{2}{c}{ Faktor risiko } & Kasus & Kontrol & Total & $\begin{array}{c}p \text { value } \\
\text { Cl 95\% }\end{array}$ & OR \\
\hline $\begin{array}{l}\text { Lama penggunaan } \\
\begin{array}{l}\text { analgetik dan } \\
\text { OAINS }\end{array}\end{array}$ & $1-10$ tahun & 16 & 4 & 20 & 0,602 & 0,5 \\
\hline Total & $>10$ tahun & 2 & 1 & 3 & $0,036-6,9$ & \\
\hline
\end{tabular}


Penggunaan analgetik dan obat anti inflamasi non steroid secara berlebihan dengan kriteria yang ditetapkan, dilaporkan 137 kasus (23,5\%) dan 196 kontrol (16,5\%), memberikan odds ratio $1,22(95 \% \mathrm{Cl} 0,89$ 1,66). Alasan utama untuk penggunaan analgetik dan OAINS adalah sakit kepala (37\% kasus dan 34\% kontrol), dan nyeri muskuloskeletal (30\% kasus dan 32\% kontrol) dan kondisi kardiovaskular dengan penggunaan aspirin (12\% kasus dan $7 \%$ dari kontrol) (Ibanez et al, 2005). Hasil penelitian kaitan jumlah tablet penggunaan analgetik dan OAINS dengan kejadian gagal ginjal kronik pada Tabel 10.

Tabel 10. Kaitan jumlah tablet penggunaan analgetik dan OAINS dengan kejadian gagal ginjal kronik

\begin{tabular}{|c|c|c|c|c|c|c|}
\hline \multicolumn{2}{|c|}{ Faktor risiko } & Kasus & Kontrol & Total & $p$ value & OR \\
\hline Jumlah tablet & 1- 500 tablet & 7 & 2 & 9 & 0,964 & 1,058 \\
\hline OAINS & $>500$ tablet & 11 & 3 & 14 & $0,138-7,934$ & \\
\hline Total & & 18 & 5 & 23 & & \\
\hline
\end{tabular}

Hasil analisis bivariat diperoleh (OR $1,1 ; p>0,05)$, maka secara statistik tidak ada kaitan yang bermakna antara jumlah tablet analgetik dan anti inflamasi non steroid dengan kejadian gagal ginjal kronik. Secara klinik jumlah tablet penggunaan analgetik dan anti inflamasi non steroid > 500 tablet mempunyai risiko 1,1 kali mengalami gagal ginjal kronik. Analgetik dan obat anti inflamasi non steroid mempunyai mekanisme yang sama sehingga apabila digunakan dalam waktu yang bersamaan dapat meningkatkan efek terhadap kerusakan ginjal.

\section{KESIMPULAN}

Riwayat penggunaan analgetik (paracetamol dan antalgin) tidak berkaitan dengan kejadian gagal ginjal ronik (OR $0,1 ; p>0,05 ; \mathrm{Cl} \quad 0,018-0,366)$, obat anti inflamasi non steroid (asam mefenamat, natrium diklofenak, kalium diklofenak, piroxicam, tenoxicam, meloxicam, ibuprofen, dan ketoprofen) berkaitan dengan kejadian gagal ginjal kronik (OR 4,4;p<0,05;Cl 0,90621,97), kombinasi analgetik dan obat anti inflamasi non steroid berkaitan dengan kejadian gagal ginjal kronik(OR 5,1;p<0,05; Cl 1,057-24,78).

\section{DAFTAR PUSTAKA}

Elseviers, $\quad$ M.M., $\quad$ DeBroe,M.E., Bengtsson,U.,1996, Analgesic nephropathy. Nephrol Dial Transplant ;11:2407-2408

Elseviers,M.M., DeBroe,M.E.,Bengtsson,U, 1998, A long-term prospective controlled study of analgesic abuse in Belgium. Kidney Int ;48:19121919

Elseviers,M.M.,Burr,F.R.,Weinberg,C.R,1998, Nonsteroidal anti-inflammatory drugs and the risk for chronic renal disease. Ann Intern Med :165-172

Fored,C.M., 2003, Risk factors for the development of chronic renal failure, Stockholm, Karolinska University Press 
Woro Supadmi

Fored, C.M., Stewart,J.H., Dickman, P.W., 2003, The analgesic syndrome. In: Stewart $\mathrm{JH}$,ed. Analgesic and NSAID-induced kidney disease.Oxford, England: Oxford University Press

Griffin, M.R., Yared,A., Ray,W.A., 2000, Nonsteroidal antiinflammatory drugs and acute renal failure in elderly persons. Department of Preventive Medicine, Vanderbilt University School of Medicine, Nashville, TN 37232, USA

Kompas, 2006, Pelayanan kesehatan pasien gagal ginjal kronik dengan hemodialisa di rumah sakit. www.kompasonline.com. Diakses tanggal 14 April 2008

Mcclellan, W.M., dan Flanders,W.D., 2003, Risk Factor for progressive chronic kidney disease; J Ant Soc Nephrol; 14:s65-s70

National Kidney Foundation, 2004, K/DOQI Clinical Practice Guidelines for Cardiovascular Disease in Dialysis Patients

Price, S.A., dan Wilson,L.M., 2002, Pathofisiologi Konsep Klinik ProsesProses Penyakit. EGC. Jakarta

Strong, T.W, Stevens, L.A., Coresh, J., Greene.A, Schonder, K.S., 2005, Chronic and End Stage Renal Disease in Chisholm-Burns et al (Eds.) Pharmacotherapy : Principles \& Practices, McGraw-Hill,New York, hal. 373-402

Suhardjono, Lydia, A., Kapojos, E.J., Sidabutar, R.P.,2001, Gagal Ginjal Kronik Buku Ajar IImu Penyakit Dalam Jilid II Edisi 3. Jakarta: FKUI 